Portland State University

PDXScholar

Fall 2009

\title{
"A Caretaker Responsibility": Revisiting Klamath and Modoc Traditions of Plant Community Management
}

Douglas Deur

Portland State University, deur@pdx.edu

Follow this and additional works at: https://pdxscholar.library.pdx.edu/anth_fac

Part of the Anthropology Commons

Let us know how access to this document benefits you.

\section{Citation Details}

Deur, D. (2009). "A Caretaker Responsibility": Revisiting Klamath and Modoc Traditions of Plant Community Management. Journal of Ethnobiology, 29(2), 296-322.

This Article is brought to you for free and open access. It has been accepted for inclusion in Anthropology Faculty Publications and Presentations by an authorized administrator of PDXScholar. Please contact us if we can make this document more accessible: pdxscholar@pdx.edu. 


\title{
"A CARETAKER RESPONSIBILITY": REVISITING KLAMATH AND MODOC TRADITIONS OF PLANT COMMUNITY MANAGEMENT
}

\author{
Douglas Deur
}

\begin{abstract}
Conventionally, the Klamath and Modoc Indians of south-central Oregon and northeastern California are depicted as hunter-gatherers, who took no active role in the management of plant communities. In the course of a multi-year ethnographic effort, however, tribal elders have identified a complex of interrelated plant management practices that are consistent with contemporary definitions of plant cultivation. These include the management of black huckleberry (Vaccinium membranaceum) yields in subalpine environments, the management of marsh-edge environments for yellow pond lily (Nuphar polysepalum), the tending of "epos" or yampah (Perideridia spp.) digging sites, and the selective harvest of tree cambium, sap, and wood-especially from pines (Pinus spp.) and junipers (Juniperus spp). Together, these accounts suggest that plant management was widespread, that it often served to geographically concentrate culturally preferred species, and that it was rooted as much in cosmological motivations as economic ones. Factors contributing to the decline of traditional management practices are also briefly addressed.
\end{abstract}

Key words: Klamath, Modoc, plant cultivation.

A los indios Klamath y Modoc se les suele considerar cazadores-recolectores y por ello se opina que no influyeron activamente en el manejo de las comunidades vegetales. Sin embargo, durante un estudio etnográfico en el que se encuestaron durante varios años a ancianos y otros miembros de la tribu, se registraron un conjunto de prácticas de manejo que pueden considerarse dentro de las definiciones modernas de cultivo. Entre ellas están el manejo del arándano (Vaccinium membranaceum) en ambientes subalpinos, del nenúfar (Nuphar polysepalum), en márgenes de pantano, el cuidado de las zonas de escavado y recolección de "yampah" (Perideridia spp.), y la recolección selectiva de savia, cambium y madera, sobre todo de pinos (Pinus spp.) y sabinas (Juniperus spp). Todo ello sugiere que el manejo de plantas era muy intenso y que solía servir para que en determinadas zonas hubiera una mayor concentración de las especies culturalmente preferidas. El estudio también sugiera que el manejo respondía a motivos económicos y estaba enraizado en la cosmovisión local. Los factores que han contribuido al declive del manejo tradicional se exponen brevemente.

\section{Introduction}

Occupying the high desert borderlands of Oregon and California along the eastern flank of the Cascade Range, where vast and shallow lakes drain into the headwaters of the Klamath River, the Klamath and Modoc peoples carved out a unique mode of life. The territories of these two tribes are contiguous, situated in a geographical position that is intermediate between Plateau, Northwest Coast, Great Basin, and California culture areas (Figure 1). These two closely-related tribes possess shared cultural attributes that are conventionally associated with each of these regions and yet do not conform to the cultural blueprint of any one 


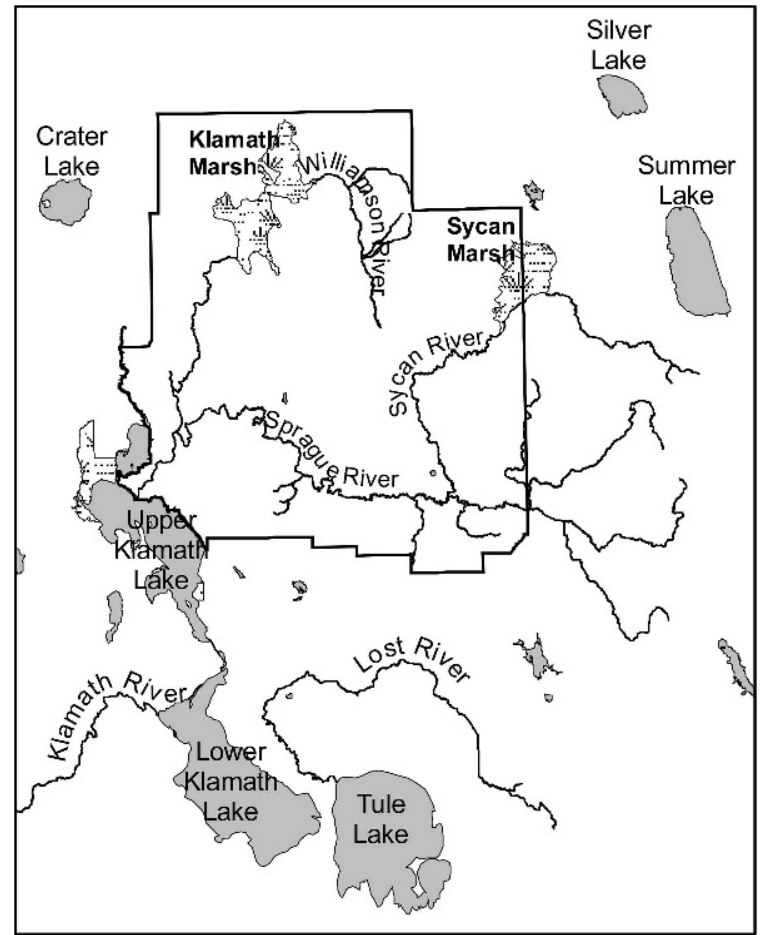

FIGURE 1. Territory of the Klamath and Modoc tribes. Map produced by the Klamath Tribes GIS Analyst, Carl White.

of them. A number of authors have suggested that a highly specialized use of resources of high elevation marsh-edge habitats distinguished the Klamath and Modoc from all other ethnolinguistic groups of the region. Barrett (1910: 259260), for example, designated the Klamath as a separate cultural type, the "specialized tule culture" which was largely "the outcome of habitat in a restricted and unusual environment of large, shallow, inland lakes." Yet these peoples occupied and drew sustenance from the high-elevation sagebrush deserts of south-central Oregon and northeastern California in places far from the lakeshores, just as they seasonally occupied Cascade Range mountain camps concealed amidst dense temperate conifer forests. To be sure, the Klamath and Modoc, as well as the habitats that they have occupied for millennia, defy simple categorization (Stern 1998).

So too, the plant gathering practices of the Klamath and Modoc do not neatly fit any template that we might find within the past literatures on huntergatherers. Being situated at the crossroads between Northwest Coast, California, the Plateau, and the Great Basin, they share certain plant use practices with each region. Like their neighbors in all directions, the Klamath and Modoc are depicted in the ethnographic literature as classic "hunter-gatherers" with no knowledge of plant cultivation or animal husbandry. Likewise, early popular accounts of the Klamath and Modoc also overlooked any evidence of plant 
management. Writing in 1873, the chronicler Samuel Clarke (1960:13) noted of the two tribes, "Nature placed its fruits with in their reach and they had not to watch the seasons and plow and sow; there was no seed time for them, they waited for the harvest and had but to gather and save crops as the earth bore them in wonderful abundance." To the extent that plants were utilized, by the textbook view of the two tribes, they were supplementary to the diet and gathered opportunistically where their culturally preferred plant species were known to naturally occur (Gatschet 1890; Spier 1930; Stern 1965).

However, a growing body of work has argued that the indigenous peoples in the regions surrounding Klamath and Modoc territory - including the Northwest Coast (Deur 2000; articles in Deur and Turner 2005), California (e.g., Anderson 2005; Anderson and Blackburn 1993), the Plateau (e.g., French 1999; Hunn and Selam 1990; Peacock 1998; Peacock and Turner 2000; Thoms 1989), and perhaps the northwestern Great Basin (Couture 1978) - were essentially cultivating plants prior to European contact. This revisionist literature shares a more expansive definition of "cultivation" than what predominated in earlier generations of academic literature, now accepting cultivation to encompass a wide range of practices aimed at increasing the quantity or quality of culturally preferred plants (Deur and Turner 2005; MacNeish 1992; Piperno and Pearsall 1998; Rindos 1984; Winterhalder and Kennett 2006; papers in Zeder et al. 2006). This literature has also brought to light an abundance of ethnographic findings and other previously unexamined data in support of these claims. Until now, the Klamath and Modoc have not been addressed as part of this larger critique. This article represents an effort to present ethnographic data to support the notion that the Klamath and Modoc were actively managing plants and their habitats in a manner that enhanced the localized output of culturally preferred species. In short, they were cultivators, intentionally modifying the landscape to meet their dietary, social, and spiritual needs.

The fact that the Klamath and Modoc have not been addressed as part of this larger critique is hardly surprising in light of the paucity of published materials on the plant use traditions of these peoples generally. Over a century has passed since Frederick Coville conducted his classic research on Klamath ethnobotany, a side project undertaken during his botanical surveys of the proposed Crater Lake National Park. On the basis of these investigations, Coville produced synopses that largely served to list plant species used by the Klamath (Coville 1897) and to draw attention to their relatively unique industry centering on the harvest and processing of yellow pond lily seeds (Nuphar polysepalum Engelm.; Coville 1904). His work largely superseded the work of Albert Gatschet (1890), who had gathered considerable ethnographic information, albeit relatively little ethnobotanical information, while working with the Klamath and Modoc in 1880. Coville's work served as the principal foundation for the ethnobotanical references made by subsequent researchers addressing the two tribes, including Spier's monumental Klamath Ethnography (Spier 1930), though Spier was able to augment Coville's data with a number of new ethnographic details. A generation later, Verne Ray (1963) added somewhat to the understanding of Modoc ethnobotany in the course of his larger Modoc ethnography, Primitive Pragmatists. Since Spier and Ray, there 
has been little of substance recorded of Klamath or Modoc ethnobotany outside of a smattering of accounts in the gray literature. Thus, in addition to remedying past misrepresentations of Klamath and Modoc plant management strategies, the current article is also motivated by the simple aim of expanding on what little has been written generally regarding the ethnobotanical practices of these two tribes.

Here, I make the case that the Klamath and Modoc actively managed plant communities at multiple scales to enhance the availability of culturally preferred plant species. This article draws on four principal examples: the management of black huckleberry (Vaccinium membranaceum Dougl.) yields in subalpine environments, the management of marsh-edge environments for yellow pond lily (Nuphar polysepalum), the tending of epos or yampah (Perideridia spp. Reichenb.) digging sites, and the selective harvest of tree cambium, sap, and wood - especially from pines (Pinus L.) and junipers (Juniperus L.). While there are a number of other examples of plant management to be found among these two tribes, these four case studies are representative of what appears to be a constellation of interrelated practices that all center on the intensification of plant resources - the quantitatively or qualitatively increased production of culturally preferred plants above levels found in naturally-occurring plant populations (Brookfield 1981). They are also the four varieties of plant management that have received the most attention from the elders who participated in interviews on the general theme of land and resource management. Taken together, they suggest that plant management was widespread, that it often served to geographically concentrate culturally preferred species, and that it was rooted as much in cosmological motivations as dietary ones.

This article relies principally on contemporary ethnographic interviews. Specifically, its contents are gleaned from over 250 original ethnographic interviews on the topic of traditional land and resource management, conducted with members of the Klamath Tribes-the federally recognized tribe that now represents most Klamath and Modoc descendents-by the author as ethnographer for this tribe. Interviews quoted here date from 1999 through 2008. Direct quotations are italicized; individual interviewees are not identified in the text, but a complete list of quoted tribal members is included at the end of the article. ${ }^{1}$ At this point in history, tribal members do not always describe past plant management practices identically, and clearly there have been many changes in the cultures, technologies, and economies of these two tribes since European contact. However, tribal members' accounts of pre-contact and immediately post-contact plant use traditions share consistent themes that, taken together and compared with other regional examples, provide consistent and suggestive hints of pre-contact management practices. Available ethnographic data alone do not allow one to provide a detailed account of the pervasiveness, scale, or precise antiquity of these practices, but we can be fairly certain that the accounts of so many tribal elders, gathered over the course of a decade, confirm that plant cultivation was practiced and the potentials for plant cultivation were understood by the pre-contact Klamath and Modoc peoples. 


\section{Subalpine Huckleberry Management}

Among the plant gathering areas that have been used and managed by the Klamath and Modoc, few were as important as the huckleberry picking areas in the subalpine zone of the Cascade Range Mountains. Iwamkani, a place in the mountains west of Crater Lake whose name literally means "Huckleberry Mountain" in the Klamath language, has been perhaps the most important and enduring. ${ }^{2}$ Well before European contact, multiple tribes including the southern Molalas, Upper Umpquas, Takelmas, and Shastas visited this mountainous berry picking area along with the Klamaths and Modocs. These groups converged at this place annually to gather berries and other plant products, to hunt, and to socialize. While all area tribes maintained discrete territories, resource rich subalpine areas at the territorial boundaries were commonly shared areas, with multi-tribal patterns of use. Berries gathered at Iwamkani, particularly black huckleberries, were a significant component of the traditional diet for all of these tribes. Moreover, seasonal camps at Iwamkani provided tribes with access to many upland plant and animal resources that were uncommon in their lands in the lower-elevation basins. This was especially so for the Klamaths and Modocs, with their relatively arid but well-watered territories east of the Cascade Range. Iwamkani thus became a cornerstone of the seasonal round, and one of the most important sources of foods, materials, and medicines to local tribes - a role that it still maintains, in a much reduced capacity, today.

On the eve of European contact in the mid-19th century, the annual return to Huckleberry Mountain followed a regular rhythm. As summer arrived and the snows retreated from the huckleberry camps, families packed their provisions and followed established trails to the mountain's summit. Once at Iwamkani, family groups dispersed to their own campsites. Tribal interviewees consistently indicate that all lands and resources on this particular mountain were subject to some form of tenure; families returned each year to the same campsite, which was inherited matrilineally. Camps were often located at the tops of slopes, with extended maternally-related families staying in campsite clusters, often adjacent to small anthropogenic clearings used for social gatherings and food processing. The campsites served as bases for wide-ranging gathering and hunting activities in the adjacent terrain. Each morning, women, children, and the elderly fanned out to the huckleberry patches downslope from the camps where they gathered berries in baskets and other containers. Families returned to their camps each afternoon, spreading the berries on mats in forest clearings so that they would dry in the sun and thus be preserved for later use (Deur 2002b).

The terrain spreading for miles around the campsites at Iwamkani provided a wealth of other resources. A number of food plants were gathered in riparian areas and spring-side meadows of the subapline and adjacent montane forest zones, while some families participated in specialized harvests of medicinal plants and plants used for basketry, dyes, and other purposes nearby. While women, children, and the elderly picked and processed berries and other plant products, groups of men fanned out to a diffuse constellation of resource sites around the mountain's perimeter. To the west, Klamath families claimed salmon 
fishing sites on the upper Rogue River. Elsewhere, groups of male kin returned to their hunting areas, which were loosely inherited down the male line. Every few days, the meat and fish that the men had gathered was taken back to the campsites at Iwamkani where it was dried in the open meadows adjacent to the camps. After an overnight stay, the men fanned out to hunting and fishing sites again while women completed processing the fish and meat. So this cycle of activity continued, with its feminine core and masculine periphery, week after week through the entire summer stopping only once the snow began to fall. At summer's end, families gathered up the processed meat, fish, and berries and started home. These foods sustained Klamath and Modoc families through the following year, until the cycle began once again (Deur 2002a, 2002b, 2008).

While a number of factors conspired to reduce the intensity of use at Iwamkani during the late $19^{\text {th }}$ and $20^{\text {th }}$ centuries, Klamath Tribes members have continued to take abbreviated berry harvesting trips to the mountain to the present, and a few families still occupy their campsites. Automobiles facilitate single-day picking trips to the mountain from homes in the Klamath Basin, and while a family may take multiple trips in a year, overnight stays are comparatively rare. During the height of huckleberry season, there are few Klamaths today who are not aware of the status of the ripening berries.

Interviews with contemporary tribal members suggest that at certain key huckleberry gathering sites, including those at Iwamkani, the Klamath took steps to intensify the productivity of their preferred huckleberry patches. Families maintained usufruct rights to picking in desirable patches close to their camps, so that tenure, in truth, encompassed both camps and adjacent picking areas; to pick extensively close to another family's camp was, and often still is, depicted as a violation of the traditional order. Several consultants mention that fire was traditionally used to enhance berry output on Iwamkani. Similar patterns have been reported in a number of other ethnographic contexts within Northwestern North American, including the southern edge of this region (see Boyd 1999; French 1999; Hunn and Selam 1990; Hunn et al. 1998; LaLande and Pullen 1989; Lepofsky et al. 2005; Mack and McClure 2002; Pullen 1996; Trusler and Johnson 2008). While oral traditions regarding the use of fire for vegetation management persist, no interviewees recalled these methods first-hand. Interviewees recall being told that burning was generally carried out every other year at Huckleberry Mountain through the 19th century. Fires were set at the end of the season, as people were leaving for their communities in the basins below. Burning also appears to have occurred at multiple scales depending on the motives underlying each burning episode, but little oral tradition persists on this point. Klamath consultants widely recognized that fire served to enhance several important resources and "whenever there was a fire, the huckleberries come back better." Fire probably also served to improve "secondary resources" at Huckleberry Mountain as well, maintaining foraging areas for elk and deer, maintaining clearance around campsite areas, and encouraging the growth of edible earlysuccessional plants such as cow parsnip, camas, hazel, and a number of different berries.

Further, the Klamath and possibly other groups appear to have enhanced berry productivity at Iwamkani through first food ceremonies and other rituals 
conducted as part of the harvest. Some interviewees suggest that people had to "feed the earth" there and if this respect was shown properly and regularly, "you would always find lots of berries." A small number of elderly women in the tribe recalled that the central focus of this ritual effort was the "first huckleberry ceremony." One tribal elder recalled:

The old Indians used to tell us that you had to take the first berries that you gathered up and throw them to the ground, and give them back to "Mother Earth." It was an offering. That was their belief...so I had to offer the sacrifice there. And that was a sacrifice, too... it was terrible, because it was hard for me to pick - I was a little girl...It took me a long time to fill a little bucket like that!... They did it with fish, and deer and whatnot - anything [that was] the first. And then you will be very successful through the years... the berries would come back better that way.

This individual was taught this tradition by elders born in the $19^{\text {th }}$ century who reported that they, in turn, had learned the tradition from elders born prior to Euro-American settlement in the Klamath Basin. "They scattered them around the camp [but also] anyplace." In this way, the pickings from the first few days ultimately found their way to the ground in the prime berry picking areas surrounding the campsites. The women were apparently responsible for conducting this ceremony: "I think that all of the women did it when they started picking, when they went up there each year." By gathering berries from numerous picking areas, regrouping at campsites, and tossing berries to the ground annually, these people effectively reseeded huckleberries in the vicinity of their camps. This, combined with annual burning practices, would have contributed to the visually apparent high-density huckleberry understory in the immediate vicinity of traditional campsite areas, which have been observed in field visits associated with this research effort. Today, in areas where traditional maintenance was the most intense, the forest understory still consists of an almost unbroken monoculture of Vaccinium membranaceum, a likely outcome of these traditional patterns of resource management. Still, Klamath consultants indicate that the number and fecundity of huckleberry plants in the forest understory is noticeably declining, while anthropogenic meadows once used for campsites are being overgrown with lodgepole pine (Pinus contorta). It appears that, in the absence of anthropogenic management, these environments will not persist.

\section{Marsh Edge Management for Yellow Pond Lily}

Most important among the plant resources traditionally used by the Klamath and Modoc, perhaps, are the seeds of the yellow pond lily (Nuphar polysepalum) called wokas in the closely related languages of Klamath and Modoc. This plant is found especially in shallow, slow-moving water within the many marshes and lakeshores of the Klamath and Modoc territory. The two tribes have traditionally gathered the seeds particularly on Klamath Marsh, but also in a host of other shallow water environments along Upper and Lower Klamath Lakes, Tule Lake, and myriad smaller waterways within the larger Klamath Basin. Each year, as the 
showy yellow flowers gave way to urn-shaped seed pods, the Klamath, in particular, relocated to seasonal villages centered on prime lily gathering areas. While the ripe seed pods could be gathered by wading through the marshes, woman commonly gathered these pods from dugout canoes. On the shore, families parched, hulled, winnowed, and then stored the seeds for later use (Coville 1904; Spier 1930:160-162).

Despite that fact that yellow pond lilies are found throughout the western United States, only the Klamath, Modoc, and a small number of associated Paiute groups used them in this way and with this intensity (Coville 1904). Of all the specializations of the "specialized tule culture" posited by Barrett (1910), perhaps none was as distinctive as the use of wokas seeds. These seeds represented a staple of the Klamath diet second only to fish in importance and unmatched by any other plant food; while somewhat less central in the Modoc diet, the gathering of wokas still represented an important supplementary contribution to the overall diet. The plant persists as such a potent cultural emblem that the annual condition of the wokas patches is still known by much of the tribe in season and the term "wokas" is still employed universally today, even by those tribal members who speak little else in these languages (Deur 2006). Subsistence tasks were sharply divided by gender, and wokas harvesting was no exception. While at the wokas gathering villages, "Women only gather wókash, the men hunt mule-deers, antelopes...Root and seed gathering is women's work." (Gatschet 1890:74, 144). Spier (1930:52, 104) depicts the wokas seed and the punt pole for the wokas canoe as symbols of femininity in Klamath oral tradition. Women used bags of seeds to facilitate their infants' cranial deformation - an emblem of prestige and free birth (Hrdlička 1905).

The practice of intensive wokas harvest persisted after the development of the reservation in the years following the 1864 treaty. Through the early $20^{\text {th }}$ century, the wokas harvest brought together nearly every Klamath Tribes family, especially at Klamath Marsh. Writing in the late 19th century, Gatchet (1890:74, 152-153) noted, "The season of the year, when the exodus of the whole tribe to Klamath Marsh takes place, where pond-lily seed is collected for the winter, is about the middle of June" and no less than a full month was assigned to the gathering and processing of wokas seed at this site. In 1873, Clarke (1960:15) observed families converging at wokas gathering sites:

During July and August the women go to the lake sides and marshes and still water places where the long-stemmed yellow water lily grows and gather the precious wokus, rarest and most of a luxury of all Indian food. The lily pod is large and contains many small seeds; these are gathered, the seed shelled out and hulled by some slow process and then the wokus is ready to be parched and eaten.

Gatschet (1890: 75) recorded that the 19th-century wokas harvests he observed involved such large quantities of seed that horses were needed to haul the load, returning for repeat trips over the course of two or more days; these horses were sore and had to recuperate for a day after the hauling was complete due to the weight of the seeds being harvested. Contemporary interviewees indicate that this account did not reflect the full intensity of the harvest, and that harvest of 
wokas extended throughout June through September, with seeds being gathered, with horses and wagons making repeated circuits between peoples' homes and prime gathering areas to carry the harvest.

The specialized subsistence practices focusing on wokas procurement were manifested in the material culture of the Klamath and Modoc in myriad ways, suggesting the overall importance of wokas harvests in the cultural traditions of these peoples. Tribal craftspeople fashioned specialized dugout canoes, punt poles and harvesting sticks for waterborne wokas gathering, which was especially intensive during the early summer, before the marshes began to dry. Contemporary tribal interviewees often discuss the traditional construction of specialized dugout canoes for gathering wokas, designed so that they could be maneuvered by a single woman if necessary, but made of large logs and of such a draught that large quantities of wokas could be gathered before a person had to return to shore (see also Gatchet 1890:32). Interviewees recall that these canoes were submerged at prime wokas gathering sites with large heavy stones, in order to prevent damage from hard freezes or other forms of weathering and to ensure their availability for the next year's harvest (see also Gatschet 1890:77). Later summer harvests were often accomplished without canoes, but instead by the use of footwear, structurally similar to snowshoes, designed for this purpose, footwear which allowed pickers to traverse the mud at low water; these may have sometimes been used along with walking poles, similar to ski poles, for stability (see also Davidson 1937:19). Some consultants recalled oral accounts of "houses" or other structures being constructed on pilings in shallow, perennially submerged portions of the marsh for use during the wokas harvesting season. These houses were occupied only temporarily. Stone metates and hand mortars are traditionally used to grind wokas seeds, while processing bowls also have been documented archaeologically in wokas gathering sites (Carlson 1957). Clearly, the Klamath and Modoc people were deeply invested in the wokas industry.

Despite the apparent abundance of wokas, the seeds were difficult to gather. Kroeber (1925:325) noted, "the food was a high grade and industrially costly one... It is a fair estimate...that a day's labor did not yield above 6 or 7 pounds of edible wokas." Spier (1930:160-161) noted:

This seems an exceptionally abundant food supply, but the difficulty is that a day's harvest is relatively small. A woman may pick from four to six bushels of pods in a day, but the seed content is only one-fourth as great. Gatschet's informant implies that the season's activities netted an individual seven to ten sacks of ground seed, each of fifty points content.

At the time of first Euro-American contact, early writers depicted the natural abundance of wokas as enormous, and the plant as essentially representing a monoculture within the principal gathering areas frequented by the Klamath. Reporting in 1925, Kroeber (1925:325) noted, "Klamath Marsh alone contained 15 square miles of solid growth of water lily." Spier (1930:160-161) reported, "Klamath marsh alone contained 10,000 acres of the plant in 1902." These authors did not query the origins of this bounty but appear to interpret it as a natural phenomenon. 
Ethnographic interviews with contemporary tribal members gathered in the course of this research might suggest otherwise. The methods employed to intensify the wokas, importantly, appear to have not so much increased the gross quantity of the wokas resource within Klamath and Modoc territories above some natural limit on procurement-though it might have done this in the aggregate-but instead seem to have served to enhance the spatial concentration of wokas in predictable locations proximate to settlement sites. Consultants note that tule (Schoenoplectus acutus Muhl. ex Bigelow) and cattail (Typha latifolia L.) were available in marsh edge environments in roughly the same environmental contexts as wokas. These two plants were important in their own way, serving as a supplementary food as well as the source of raw materials for mats, baskets, floating duck decoys, and a wide range of other material goods. Yet, these two species were known to compete with wokas in many contexts. Being of a lower rank in the hierarchy of culturally preferred plants, tribal members attempted to eliminate them from the prime wokas harvest areas.

The Klamath and Modoc appear to have taken steps to remove plants that competed with wokas through the use of fire and weeding. Tribal interviewees recall accounts of Klamaths burning the edge of the marsh at the end of the summer to foster annual regrowth of wokas in areas that would otherwise be dominated by tules and adjacent upland vegetation. "People used to burn the marsh in the summer...You can still see those [scars] on the trees around the marsh where people used to do that." Only in the late summer or early fall did the vegetation dry to the point that it could be readily ignited. Tribal interviewees note, "the wokas came back better when they did that" (see Boller 1972; Lewis 1982; Minto 1898). Likewise, a number of families retain stories of "weeding out tules" so that the wokas grew better in areas that were not burned. Indeed, there is a much richer oral tradition regarding this practice compared to burning, perhaps reflecting the persistence of weeding until recent times. The practice of weeding competing vegetation from preferred wokas patches was observed by a number of families into the mid-20th century: "that was my job. My grandma used to send us kids out to pull up the tules out of the wokas when we was out camping so that the wokas would come in better the next year." Interviewees consistently depict these practices as being of precontact origin.

Some ethnographic evidence also suggests that wokas was scattered in these recently cleared areas ritually as part of a first food ceremony similar to that used for huckleberries. A small number of tribal elders suggest that women may have gathered up the first harvest and scattered it back to the ground in close proximity to their seasonal villages. They did this, some suggest, as a kind of offering: "returning to the earth I guess, returning it to their spirits." While this practice is not as clearly recalled as those pertaining to huckleberry and epos, it is consistent with the larger Klamath and Modoc first food ceremony tradition.

Waterborne wokas harvesting was said to be intentionally configured in a "zigzag" pattern across the marsh, largely to minimize localized overexploitation of the resource. Starting from one point on the shore, individuals commonly choose a landmark on the distant shore and paddle to that landmark, gathering wokas pods as they travel. "You choose a place on the opposite side. You kind of line up with it and then you go across, picking. When you get to the other side, you can turn 
around and choose another place on the other side and go across. You go back and forth that way until you have filled up your canoe." After two days, it was said that the process could be repeated in the same general area and new pods would have ripened in the interim: "you go back and do it over again." Seed harvesters recognized that prolonged picking in one location would exhaust the supply in the short term, possibly reduce seed reproduction in the long term and, in turn, possibly increase the amount of labor required to find available seed pods in a matrix of harvested patches. Cumulatively, this process appears to have geographically randomized the harvest of wokas and thereby reduced the threat of localized exhaustion of the wokas resource (Deur 2006).

There is also modest evidence that the outlets of lakes were obstructed in part to raise water levels and expand the total area of these shallow marsh-edge environments. After a brief investigation of Klamath tribal dam-building customs during the 1880s, William Clarke (1885:41) noted, "The shallow outlet of Big [Upper] Klamath Lake has been caused by the aforesaid Indians, who wish to confine the waters of the lake for the sake of the tule lands." It is perhaps telling that when these obstructions were removed by non-Indian settlers in the late-19 ${ }^{\text {th }}$ century, some of the most productive and expansive wokas gathering areas on the lake's margin were lost to desiccation. Yet elsewhere, even where major hydrological changes have not been made to these lakeshore and marsh environments, tribal members note the rapid contraction of once popular wokas gathering areas. Here too, as in the case of huckleberry management, the absence of widespread anthropogenic management of wokas may be contributing to the decline of the almost monocultural plant communities that are described in the contact period.

\section{Yampah Plot Management}

As the year's first fish runs tapered off in the late spring and early summer, women fanned out to root digging grounds to gather root crops. These included epos or yampah (Perideridia spp.), especially the Oregon yampah (Perideridia oregana (Wats.) Math.). During the same general season, woman gathered other, less plentiful root vegetables such as desert parsley (Lomatium canbyi Coult. \& Rose), camas (Camassia quamash (Pursh) Greene), bitterroot (Lewisia rediviva Pursh), wild onion (Allium spp. L.), and sego lily (Calochortus macrocarpus Douglas).

Epos played a major role in the economy and diet of the Klamath and Modoc and was the most important root food of these tribes (Ray 1963:198). Verne Ray (1963:181) noted that the locations of Modoc summer villages, for example, were chosen for their proximity to a combination of trout fishing and epos digging sites due to "the critical nature of the crop and because trout would be available until August." The management of yampah elsewhere in the region has been discussed by Gleason (1997), Anderson (2005:291-305), and Hunn and French (1981).

Harvests traditionally occur only during a narrow window of time in late spring and early summer when the ground is still moist and pliable and the epos roots are soft and full of sweet carbohydrates. The harvest was ordinarily done 
"after a good spring rain," to insure that the ground was pliable enough to dig. Interviewees also note that the roots must be harvested prior to the flowering of the plant, as they will not be as palatable-presumably because the sugars are largely stored in the edible roots prior to florescence: "you go out only when those little tops are up - they look like carrot tops - you weren't supposed to go out once the flower was on." During this time, large groups of women set up temporary encampments near productive root patches, harvested until the patch was completed, and then relocated their camp to the next suitable root plot. Through much of the $19^{\text {th }}$ century, the establishment of seasonal encampments at epos patches persisted. Writing in 1873, Clarke (1960:15) noted, "the apaw roots make their growth in the hollows and depressions of the hills and the ponies are got up to convey the tents and equipment to the camping places convenient thereto." In the early $20^{\text {th }}$ century, a few families persisted in this practice while others took part in day-long outings from their homes to preferred gathering sites throughout the Klamath Basin known from generations of use. Historically, men and women had fashioned digging sticks out of mountain mahogany (Cercocarpus montanus Raf.) or yew (Taxus brevifolia Nutt.) wood. From the late $19^{\text {th }}$ century and well into the mid-20 ${ }^{\text {th }}$ century, these digging sticks were gradually replaced by digging sticks fashioned from iron by tribal men who had learned blacksmithing skills. Tribal interviewees recalling the harvests of the 1940s and 1950s describe gathering more than 50 gallon containers worth of epos roots, which provided a supplementary food for the extended family over the course of the year. More recently, epos consumption has become a modest but symbolically significant subsistence practice for most families, with only a small number of families storing appreciable quantities following the harvest season.

As with the other plants discussed here, epos was the focus of a number of conservation and enhancement strategies by the Klamath and Modoc. Families recall $19^{\text {th }}$-century accounts of strategies such as selective harvesting, in situ replanting, in situ seeding, and loose patterns of usufruct tenure. Tribal members suggest that they dug every portion of the larger epos plot, but were selective, only taking mature root segments and leaving behind smaller root fragments for later use. Children were taught from an early age that the harvest involved leaving epos behind to gather the following year: "My grandma always told us not to dig all of them...leave a few to grow back." As people dug up the entire plot but reburied roots throughout the site, interviewees suggest, "it looked just like a ploughed field" following each year's harvest. In addition to leaving immature roots in the ground, the Klamath and Modoc also traditionally cleaned all of the roots at the harvesting site to ensure that the rootlets would be returned to the ground rather than discarded off-site:

My grandma said that you always clean those epos right where you dig them.

You pull all those little roots and pieces and they fall right there on the ground. When it's wet, the time that were supposed to go out, they go right back down into the ground, into the mud there... If you don't do that they start to go away.

Tribal members report seeing the plants disappear in places where tribal members have resumed annual digging in recent years, but were unaware of the old protocols and took their roots home to clean them. Often, the seed stalks 
persisted on the epos from the previous year. A small number of interviewees have mentioned that their families intentionally left the seeds behind, and often intentionally knocked seeds to the ground from standing stalks while harvesting the site: "You're really cultivating the seed when you're digging them up." A small number also mentioned weeding out competing species from their epos plots: "they would pull out the other plants as they dug...probably just tossed them to the side." The epos was also ceremonially scattered over the ground as part of a first foods ceremony, likely replanting desirable roots over the recently turned earth:

It was just like with [huckleberries] - they would do their praying and scattering that way, bringing a handful and throwing it back to the ground. As long as you cultivate it, it always comes back. On Tableland [on the former Klamath Reservation] that's all so abundant there with epos because they always kept using it and taking care of it.

Together these practices suggest an investment in particular gathering locations that endured over time. Families returned to their preferred epos each season: "people went to the same patches of epos year after year." In some places, certain groups of families appear to have possessed the option of harvesting sites with which they possessed enduring ties, suggesting a form of usufruct tenure; in the $19^{\text {th }}$ century, as multiple village groups were relocated to the Klamath Reservation, these claims appear to have been realigned somewhat, with communities maintaining usufruct claims to the epos gathering sites that were most proximate.

Interviewees who recall aspects of traditional cultivation methods consistently report that these practices ensured an enduring supply of epos roots: "people kept going to the same small patch for weeks and weeks, but it wouldn't run out of epos." Today, they note, patches that are not cared for tend to disappear.

\section{Selective Harvest of Pine and Juniper Segments}

Like many indigenous groups throughout North America, the Klamath and Modoc have traditionally utilized pine trees (Pinus spp. L) - especially the lodgepole pine (Pinus contorta Dougl.) and ponderosa pine (Pinus ponderosa Dougl.) - for diverse purposes. In addition to the obvious value of these trees as a source of wood for fuel and construction materials, their cambium and sap served as a source of foods and medicines. An earlier generation of anthropologists researching Klamath and Modoc resource use commented particularly on the importance of peeling pine cambium for food, a practice that has been documented in a number of other tribal contexts (Swetnam 1984). Coville (1897:89) described the Klamath use of the cambium of ponderosa pine:

In the spring, usually in the month of May, a broad strip of the bark is removed, and the sweet mucilaginous layer of newly forming tissue (stop'-älch) between the bark and the sap wood is scraped off and eaten... in April the cambium layer of [Lodgepole pine also] is scraped off and eaten, either as a relish or in time of famine, in exactly the same manner as the inner bark of the yellow pine. 
Subsequent anthropological accounts (e.g., Spier 1930) largely followed Coville in their description of cambium use.

Among the contemporary elders of the Klamath Tribes, trees with peeled cambium are still a part of their living memory and their landscape. When asked about the cambium peeling, tribal members report an enduring knowledge of the practice and often associate it with fond childhood memories: "When I was a kid, we used to go out peeling cambium all the time. We used to go out every spring." Another remarks, "I've heard elders talking about eating cambium off of trees...I've gathered it myself for different things." A third remembers, "My mother showed me how to do this in the beginning, when I was a kid. This was up at Klamath Agency. She just chopped the bark off - the outer layer of bark until you get down to that inner part, just right before the wood. You just peel that out. That was the sweet part!"

The cambium was generally pulled from the tree in a single, long strip from a horizontal cut in the bark; the rest of the tree was left undamaged, and in time the scar gradually healed. The cambium layer peeled in this manner was said to serve multiple functions, being considered a dessert by many, but also serving as a hunger suppressant, an easily acquired food when traveling, and a food with medicinal properties. Contemporary tribal members generally take issue with the depiction of cambium as a "famine food," asserting that it was highly prized for diverse uses and also that famines were scarce. The sap from these trees was also prized as a food, medicine, and "gum" and is widely used by tribal members into the present day. The acquisition of sap is generally not as damaging to the tree as cambium peeling, but involves making simple cuts in the bark of the tree at points where the sap is gathered. Some families maintain "pitch trees" in places they frequent, returning year after year to gather sap and sometimes to reopen the cut in the bark for later use (Deur 2007).

In all cases, Klamath and Modoc interviewees assert that it is essential to take only a strip of bark from an individual tree rather than stripping away all of the bark. Indeed, some families report having maintained entire groves of trees, each with its own cambium peel scar, when the amount of cambium gathered would have, together, been equal to that of a single tree. When asked why the Klamath and Modoc traditionally peeled only a portion of the tree rather than taking all of the bark, tribal interviewees have consistently cited traditional concepts of interspecific ethics - a practice that has been clearly documented elsewhere in northwestern North America (e.g., Hunn and Selam1990; Hunn et al. 1998; Swezey et al. 1975). In part, these values were rooted in oral traditions that described trees and other organisms as sentient beings that willingly accepted their functions within human societies; by these traditions, humans had obligations to care for and honor these organisms as part of a reciprocal obligation that binds humans to particular plant and animal communities. According to these Klamath and Modoc traditions, most suggested, a person would not kill a tree unnecessarily:

The Creator gave us those - you don't abuse what the Creator gave you to survive...you don't abuse the things that you rely on...we have kind of a caretaker responsibility for those trees. They take care of the birds, the wood we 
need, the forests that help keep the fish alive. It's all about mutual respect. They take care of us so we take care of them.

Or, as another consultant questioned on more material grounds, "Why kill the whole tree for something [small] that you need? ...eventually it will heal itself" and a person can keep going back for more in the future.

In addition, peeled trees were said to have their own intrinsic resource value. While most consultants discussed cambium peeling and sap harvesting as separate activities, a few individuals clearly recalled using trees with cambium peels as a source of sap for years following the initial peel. To a degree, this practice reflected Klamath and Modoc perceptions of pine cambium and sap as being both food and medicine: "We kept it open after it was peeled... So there's that dual purpose there - you've got that food supply the first time you're opening it up, but later you can always go back and you've got that pitch for medical purposes." The practice of drawing sap from former cambium peels involved revisiting peeled trees to reopen the cambium around the perimeter of the existing scar and thereby reestablish the flow of sap. This typically involved scraping the margin of the peel with a tool:

Every springtime, [we would] just go out there with an axe and hit it around a little bit more, kind of open it up. Just kind of chop away at the bark to open it. I always tried to leave in that inner bark, because it seemed like you got more of a run if you left that inner bark than you did if you took it off. So we just kind of chop around it.

Certain groves of pines were revisited each year for this purpose. The trees in these groves were revisited with such frequency that they did not fully heal, but continued to emit sap through much of the year, probably stopping only in the wintertime.

This kind of selective harvesting was applied to a variety of plant species in addition to pine trees. Juniper (Juniperus spp.) is among those trees traditionally harvested in this manner. Wood was sometimes harvested directly from living trees, often in a year-long process:

The juniper - you might find one where there's a piece missing off of it...in the old days, that was how they used to make their bows. They would take and notch a part up here and notch a part down there, and then they would seal that. And that would die and age right on the tree and they kept that sealed so the air couldn't get to it. And then after a year or so, then they'd go back and they'd wedge that out...because if you just pulled that out it would pop apart on you, because it would dry too fast.

Klamaths and Modocs traditionally used pine pitch to seal these temporary stave cuts on juniper trees. Recently, tribal members report that they have used beeswax and other sealants for this purpose. Once the stave was removed from the tree, this left a scar that partially healed with time, in a manner reminiscent of the pine trees. This practice is said to have been easier than cutting down the entire tree but was also consistent with cosmological prescriptions regarding tree harvest (Deur 2007). 


\section{The Decline of Traditional Management}

The Klamath and Modoc experienced the indirect effects of European exploration in the early $19^{\text {th }}$ century, such as the arrival of horses and new trade goods, while their first recorded contact with Euro-Americans occurred in 1826, when Peter Skene Ogden of the Hudson's Bay Company first visited their territories. Nonetheless, the non-Native world had little impact on daily life until the years following 1846, when the Applegate Emigrant Trail was first routed through the Klamath and Modoc homelands; while non-Native settlement in the area was negligible, the development of this trail placed the Klamath and Modoc in frequent and sometimes awkward juxtaposition to wagonloads of arriving settlers passing through their high desert territories. Only after 1864, following the signing of a treaty with the Klamath, Modoc and Yahooskin Snake peoples, did non-Native agricultural settlement take hold within these lands. However, it was not until after the Modoc War in the 1870s that agriculture began to significantly alter the human and natural landscapes (Stern 1956, 1965).

While the memory of plant intensification methods have persisted into the present day, it is safe to suggest that these methods have largely ceased their roles in the dietary practices of the two tribes or in the shaping of their landscapes. The decline of traditional management practices, tribal members suggest, is rooted in a complex web of causes emanating from the circumstances of Euro-American contact. The discovery of new foods and technologies, arguably starting in the late $18^{\text {th }}$ and early $19^{\text {th }}$ century, prior to direct European contact, proceeded rapidly in the years following direct contact, expanding and rearranging traditional social relations and modes of food procurement. Simultaneously, the Klamath and Modoc clearly underwent a demographic contraction as new diseases passed through their communities, possibly resulting in the "disintensification" of traditional resource practices (cf. Brookfield 1981).

However, when asked to explain the decline of traditional management practices, tribal interviewees consistently cite the experiences of the reservation era (1864-1954) as being causative. The Klamath and especially the Modoc actively resisted removal to the Klamath Reservation, culminating in the events of the Modoc War of 1872-1873. In response, the functions of the Klamath Reservation became increasingly acculturative and carceral from the 1870s onward. Certainly, the retention of land within the reservation did not ensure tribal sovereignty over tribal land and culture. As Stern (1998: 460-461) suggested of the tribe, "the reservation had been created to effect the acculturation of the Indians within about a generation." Missionaries and Indian agents became the social architects of the newly formed reservation. Placed in autocratic control of daily life, both had the mandate and the means to stifle traditional ceremonial and resource use practices. The Klamaths became captives on their own land.

Plant gathering and other subsistence pursuits were prohibited beyond the boundaries of the reservation, and the Klamath Indian Agent's written permission was required to leave the reservation boundaries (Stern 1965). "You couldn't go anywhere in those days, all the places we used to go. People had to get permission to leave. You had to sneak out to hunt, to fish...to do anything." 
Concentrated together within the reservation's borders, the Klamath underwent dramatic cultural changes under the direction of individuals appointed to convert them to Christianity, to replace their native language with English and their seasonal resource harvests with the more settled pursuit of agriculture (Stern 1965, 1956). Traditional forms of knowledge, particularly those related to women's pursuits and landscape management practices beyond the reservation boundary, were especially threatened.

The Klamath Indian Agency had as one of its primary goals breaking the ties between the Klamath, Modoc, and Yahooskin peoples and their traditional land base, in part to extinguish competing claims to lands being rapidly reoccupied by non-Indian settlers. The Agency was unusually responsive to the demands of the non-Indian community beyond their borders, which increasingly viewed the tribes as competitors for lands and resources such as water. By the 1880s, nonIndian settlers were seeking ways to drain and "reclaim" wetland margins of the Upper Klamath Basin lakes. There is a movement on foot [among non-Indian settlers] to remove these obstructions at the mouth of Link River. Such being done would decrease the depth of the lake a foot or so, and make thousands of acres of land arable that are now nothing but tule (Clarke 1885: 41). Soon, the Klamath Indian Agency was advocating the draining of vast wetland areas within the Upper Klamath Basin in order to both increase agricultural acreage and to eliminate the continuation of traditional subsistence opportunities that competed for the time, labor, and attentions of native peoples (cf. Knack and Stewart 1984). Indeed, Indian Agent Horace Wilson (1906) advocated draining the entire Klamath Marsh - the centerpiece of the Klamath wokas industry toward these aims. This remained the position of the Klamath Indian Agency for decades, as they sought to reclaim lands that would hasten the conversion of the Klamath to "true agriculture." While successful in fostering this conversion generally, portions of the Marsh persisted in its original form, and the harvesting practices of its original inhabitants persisted at the site.

Traditional management was undermined by other Indian Agency initiatives. The Cascade Range Forest Reserve was established in 1898 and began an active campaign to eliminate any fires that might reduce the quantity of merchantable timber in the Cascade Range. The Klamath Agency quickly adopted a campaign to eliminate the tradition of prescribed burning. Klamath Indian Agent O.C. Applegate (1899:310-311) spoke of these issues in his 1899 annual report to the Commissioner of Indian Affairs:

The Indians are more and more becoming an agricultural people and devote very little time to their former methods of providing food. Little hunting is done except in the fall of the year when the annual incursion is made is made into the Cascade Mountains in search of wild fruits and game. This usually consumes the greater part of the month of September and a portion of October and is participated in by a large number of both whites and Indians.

A police force is maintained in the huckleberry country during this season to preserve order and prevent the spreading of fires. No party of Indians is permitted to go on these excursions into the forest reserve 
without being duly instructed as to our game laws and fully impressed as to the importance of preventing the starting of fires. I am quite certain that the destructive fires which annually devastate large areas of our timberlands are not usually traceable to our Indians...

In 1902, the year that Crater Lake National Park was created a short distance from Iwamkani, Agent Applegate (1902:308) suggested in his report to the Commissioner of Indian Affairs that the area was being patrolled with greater intensity to curb the practice of anthropogenic burning:

These great areas, lying high in the Cascades, have as usual been visited by the Indians during the autumn season for the purpose of hunting and to gather wild fruit. As usual at such times, and under previous instructions from your office, I have kept a vigilant patrol of policemen in the region to prevent the violation of the game laws and the rules of the forest reserve and National Park. So far this year no such violations have been reported, and I feel that the Indians are to be commended for their careful observance of the rules which have been made for the protection of the timber from destruction by fire and for the protection of game.

During the height of these prohibitions in the early- to mid-20th century, tribal members report that burning largely disappeared, though some people still used small and quick fires in order to burn the vegetation only in the immediate vicinity of their campsites.

Though gathering sites persisted, increased economic dependence on agriculture under Klamath Indian Agency control, as well as the expanded introduction of novel foods from commercial and governmental sources, resulted in the gradual transformation of the tribes' diets and a gradual decrease in the utilization of traditional foods, plant foods in particular. Increasing participation in wage employment began to place limits on traditional subsistence activities. Novel and more persistent scheduling conflicts from wage labor on the Reservation reduced the amount of time available for extended stays at plant resource procurement sites. From the mid-20th century on, families typically do not spend several days at plant procurement sites, but those who still gather commonly drive to popular gathering areas for the day, returning home in the evening to process the plant foods (Deur 2008).

In the basins below, development, industrial forestry, and industrial agriculture rapidly displaced traditional gathering practices, especially off of the reservation (see Kerns et al. 2004). One of the most popular epos patches was built upon by a non-Native church, while others were reoccupied by new homes or cattle feedlots in the last half of the $20^{\text {th }}$ century. "It's all private land and so much has changed that it is hard to gather those plants today."

The results of this conversion were clearly not positive, as the Klamath and Modoc experienced the health effects of a riveting "agricultural transition" in the course of one or two generations (Cohen and Armelagos 1984; Kuhnlein and Receveur 1996). Accordingly, Klamath Indian Agent O.C. Applegate (1902:307308) reported significant health problems associated with the transition to a Western diet: 
When I came to this agency as the first employee in October, 1865, they were...subsisting on roots, seeds, and wild fruits, on the game that was abundant throughout the country and the fish which were extremely plentiful in the rivers and lakes...It is painful to have to admit that the changes which have come with civilization, and which have entirely removed the old conditions of life so near to nature, have not brought with them improved health and vigor...

These effects were only compounded in the years following 1954, when the U.S. Congress terminated the Klamath Tribes' status as a federally-recognized tribe, and their large reservation was disbanded. Though the Klamath Tribes regained their federal recognition in 1986, they have not yet, at the time of this writing, regained title to their former reservation or the natural resources that it holds.

Despite these changes, many aspects of traditional plant gathering practices persist today. The ceremonial foundations of plant gathering are still recalled by many members of the larger tribal community. Enduring concepts of interspecific reciprocity appear to have weathered the conversion to Christian and secular beliefs and in many cases have become a keystone of syncretic ceremonial traditions that integrate pre-contact and introduced spiritual practice (Hunn and Selam 1990; Spencer 1952; Zakoji 1953). Moreover, plant gathering sites, such as Klamath Marsh and Iwamkani maintain a high level of use and symbolic importance within the tribe, even if the food products from these places are largely of supplemental dietary value. Likewise, trees with cambium peel scars, pitch harvesting scars, or other markers are often revered among Klamaths and Modocs-in part because of these trees' significance as an emblem of traditional cultural practices. It is perhaps impossible to fully comprehend the Klamath Tribes' concern about the protection of remnant anthropogenic plant communities without an understanding of the symbolic functions of these communities as emblems of cultural rootedness, persistence, and revival in the larger tribal community. In turn, in the absence of enforced prohibitions on traditional plant management and procurement, the Klamath and Modoc now experimentally return to the practice of plant resource management in large numbers for reasons as much symbolic as dietary. While this theme is beyond the scope of the current article, such dynamics underlie many cases of modern plant community management by tribes and deserve broader consideration elsewhere.

\section{Discussion: Ritual, Geography, and Endurance}

We cannot be certain that the findings on Klamath and Modoc resource management practices presented in this article provide an unambiguous picture of pre-contact plant management. Still, the evidence compiled from multiple tribal interviewees regarding their understanding of pre-contact practices is considerable and compelling. To enhance black huckleberry yields in subalpine environments, the Klamath and Modoc burned competing vegetation, maintained usufruct gathering rights to particular patches of berries, and effectively reseeded the ground in their first huckleberry ceremonies. To enhance marsh- 
edge environments for the production of yellow pond lily seeds, the Klamath and Modoc used multiple techniques, including burning and weeding of competing vegetation, reseeding of the ground through first wokas ceremonies, and the randomization of seed harvests. In order to enhance the localized availability of epos or yampah, the Klamath and Modoc selectively harvested roots, replanted rootlets in situ, scattered seeds in situ, replanted the ground vegetatively through the first epos ceremony, and maintained loosely usufruct forms of plot tenure. In order to minimize the impacts of cambium and sap harvesting on pine and juniper trees, the Klamath and Modoc participated in selective harvesting. These examples all rely on similar methods, objectives, cosmological underpinnings, and technologies, suggesting that they were in essence part of a larger plant cultivation "complex" practiced by the Klamath and Modoc aboriginally.

The possibility that the practices identified in this article are the result of post-contact cultural diffusion cannot be wholly discounted. However, the apparent antiquity of the plant communities and ethnographic references to these practices suggest a considerable antiquity to these practices. For example, on the basis of oral history evidence, tribal members have been able to identify owners of specific huckleberry camp sites at Iwankani by name dating from as early as the first two decades of the 1800s. Interviewees consistently depict these practices as pre-dating contact, and the fact that they are consistently described by multiple interviewees speaking in isolation suggests that, minimally, the practices and their antiquity are understood consistently by the larger tribal population.

The examples addressed in this article do not exhaust the range of plant management practices that these two tribes employed to enhance the output of culturally preferred plants. For example, pruning and coppicing also appear to have been part of the repertoire of plant management practices for the Klamath and Modoc. Consultants have reported pruning and other methods to enhance the fruiting of Pacific plum (Prunus subcordata, Bentham). Some families report pruning back willow (Salix spp. L), wild rose (Rosa spp. L) and others, so that long, straight shoots will be available in the following year for use in baskets and other traditional crafts. Similarly, Klamath Tribes elders described the traditional management of sagebrush (Artemisia spp. L.) - especially the big sagebrush $(A$. tridentata Nutt.) - as part of their ceremonial traditions. Klamath and Modoc tribal interviewees suggest that sagebrush is managed by pruning or coppicing back certain branches. If this is done correctly, "it comes back fuller the following year...with more stems." As plants with particular geographical provenience are considered to possess special medicinal and spiritual power, pruning can enhance the availability of culturally preferred sagebrush within a field of less potent specimens. Historically, interviewees suggest that this may have accompanied or replaced fire management, which was supplanted by prohibitions on burning beginning in the late $19^{\text {th }}$ century. Pruned sagebrush stems are then used for a number of ritual uses. People return to the same patches year after year, and families report developing an ongoing ritual relationship with specific patches of sagebrush that can endure for more than one human generation. Patches of sagebrush are still managed in this way by some tribal members, who often visit specific patches in conjunction with annual ritual events. The range of plant management practices employed by the Klamath and 
Modoc could easily be expanded well beyond the four principal examples cited in this article.

These cultivation practices involved a variety of species within diverse habitats. The level of management also clearly operated at multiple scales, from large land-clearing fires to the burning or selective harvest of individual plants. While many of these practices are found in the repertoire of tribes nearby, in the Plateau, California and Northwest Coast regions, some - such as the management of yellow pond lily - appear to represent novel applications of broader plant management strategies. Together, these practices suggest considerable experimentation by the ancestors of today's Klamath and Modoc, facilitated by the fecundity of particular environments in their territories and the particular antiquity of Klamath and Modoc occupation that is suggested by the archaeological record (Cressman 1956).

These plant cultivation practices are nested within a larger management system that was employed to mediate both plant and animal worlds. For example, some interviewees have discussed conservation ethics and practices relating to duck egg gathering. While there appears to be variability between different families' protocols, the fundamental elements of restricting harvests to ensure future yields are shared by all. For example, one family reports, "We'd pick up duck eggs. And you always had to leave a minimum of eight eggs in a nest. So if you found a nest with nine eggs, you got one; if you found one with 12 you got four... and you weren't allowed to touch [the ones you left]." In this practice, the Klamath used special willow loops to pick up eggs so that they would not leave a human smell and scuttle the nest. As a result of these practices, interviewees suggest the duck populations were always robust, insuring the continued vitality of the duck egg harvest: "we got several dozen eggs every time we went out." First fish ceremonies and other traditions related to fish and wildlife procurement also are suggestive of intentional enhancement of subsistence animal resources (Deur 2004).

The plant management practices described in this article largely evaded the attention of an earlier generation of anthropologists who operated under an antiquated and arguably Eurocentric model of "plant cultivation." They seldom posed questions regarding land and resource management generally and devoted comparatively little attention to the domain of "women's work" (see Anderson 2005; Denevan 1992; Deur and Turner 2005; Hunn 2000; Peacock and Turner 2000; papers in Williams and Hunn 1982). Yet, clearly, the consistency of tribal interviewees' accounts regarding the intentional and repeated enhancement of particular habitats with the goal of quantitatively and qualitatively enhanced plants suggests that these people were competent cultivators - even if they may not have been "agriculturalists" in the sense of being principally dependent on cultivars and cultivation for sustenance. Likewise, the anthropogenesis of the plant communities encountered at the time of Euro-American contact are suggested by the apparent decline of certain nearly monocultural habitats (such as yellow pond lily or huckleberry patches) in the absence of human management through the $20^{\text {th }}$ century-a point that might yet be confirmed and clarified through the use of archaeological and biophysical methodologies. 
Tribal interviewees accounts are consistent in their suggestion that ritual means of enhancement were integral to the intensification of plant resources. The actions of these cultivators indicate an appreciation of cause and effect in environmental systems, refracted through the cosmological lens of the tribal community. When asked for clarification on this point, tribal interviewees note that all of the plants and animals on which the Klamath and Modoc depended were recognized as living beings, the handiwork of "the Creator" and/or other spiritual beings, and were typically said to possess a spirit. From their perspective, the harvest and consumption of these sentient and spirited beings created cosmological tensions and enduring debts. Just as with one's human neighbors, relationships with these plant and animal communities called for reciprocal exchanges and obligations. Ceremonial intervention, honoring these species and their creator, was viewed as a necessity if the staple food plants and animals were to return each year. As noted here, major resource harvests were initiated by "first food" ceremonies, including a "first mullet ceremony" a "first wokas ceremony," a "first epos ceremony" and a "first huckleberry ceremony," each carried out annually at specific resource procurement sites throughout the tribes' territories. Such ceremonies acknowledged the enduring relationships between particular human communities and particular plant and animal communities over successive generations.

Year after year, the plants and animals provided sustenance to humans, while the humans intervened both mechanically and ritually to insure the health and fecundity of their principal food species. These events consecrated and solemnified the resource harvest. In addition to this ceremonial action, the simple action of voluntary restraint from overharvest was said to be a way to "show your respect to the plants" rather than solely functioning as a mechanical method of conservation. In addition to showing respect for other species, some modern tribal members note that these practices were understood to have utilitarian consequences: "if you take care of those animals, Mother Earth, and all those things she brings forth, they will take care of you." Resource harvest sites themselves became "sacred places" in the view of many tribal members.

Accordingly, interviewees explain that many of the actions described here as part of the cultivation process were undertaken to "show respect" to the species and the spiritual beings and forces that were perceived to control their fecundity, rather than to simply act upon the mechanical forces underlying plant production. The actions of cultivation, especially the first foods ceremonies, but also burning, replanting and other actions, are commonly depicted as being ritualized expressions of the reciprocal bonds between human and plant communities. Observable outcomes in the localized productivity of these plants were taken as an indication that this ritual intercession had been successful - that, in essence, the plants, the Creator, or other spiritual forces that might control the plants' output were pleased and thus reciprocating with bountiful production of foodstuffs. This, in turn, provides encouragement for the continuation of such intercession into the future. Periods of resource shortfall were, and still often are, described as being the outcome of inadequate ritual intervention and other signs of "disrespect" to these beings and forces, rather than as the outcome of solely mechanical actions such as overexploitation. 
Even the most fundamental plant management practices, centering on anthropogenic burning, are said to have been related to ritual activities. While it is clear that this burning resulted in the production of culturally preferred plant communities, a great deal of this burning was undertaken for ritual purposes that were related to the renewal of the land and its flora and fauna. Such ritual burning is documented in a Modoc story recorded by Curtin, for example; this story outlines a variety of protocols for young men's vision quests through the retelling of the actions of Jackrabbit, which were to be instructive for later generations participating in both vision quests and anthropogenic burning. In this tale, it is noted of Jackrabbit:

He now went to the high mountain [for his vision quest]... his mother told him to go. [As] he started and at the foot of the mountain he set fire to the shrubs and bushes and followed up the fire which burned brightly. If the earth and mountains are willing to give a young man wisdom they will burn brightly and fast, but if they are not very willing, rather hold back, they will burn slowly. His mother told him that in climbing the mountains he must not hurry. He must listen for everything talked, the earth, the trees and everything that was around him. And as he followed the fire he must listen to what they said (Curtin n.d.: M-026.0).

When burning of any kind occurred, tribal members suggest that people were mediating in a relationship between humans, plants, animals, and fire that was situated within their understanding of reciprocal obligations and ritual shows of "respect" in this context. Indeed, the simple distinction between utilitarian and ceremonial fires is perhaps an inappropriate one.

Like many indigenous peoples living in the Pacific Northwest, California, and Plateau regions, it is clear that the Klamath and Modoc had tangible and enduring impacts upon the plant communities of their homelands. Today, modern tribal members and non-Indians alike traverse a landscape that still bears the imprint, fading but still perceptible, of an apparently long history of plant husbandry. While the available ethnographic evidence does not allow us to infer the magnitude of the impact of traditional management upon the aboriginal harvest of huckleberries, pond lily seeds, yampah roots, and other plants, it is also clear that these practices made tangible and welcome additions to the dietary repertoire of the Klamath and Modoc people-so important that the practices were replicated year after year, and the knowledge of these practices continued to be handed down between generations when traditional management was made largely impossible. While much of this tradition was lost to the circumstances of the reservation and forced acculturation, a renaissance in tribal identity has been accompanied by a resurgent interest in plant knowledge in recent decades. In time, here and there, the traditional forms of management may rebound. This rebound may not be uniform or widespread-too much land has been reoccupied, developed, or subject to industrial forestry or agriculture for the tribe to regain title or the land to recover readily. Still, the modern Klamath Tribes now seeks to reacquire the reservation they lost during termination, to assert claims on off-reservation resource sites, and to manage all of these places in a way that more closely resembles the ways of their ancestors from generations 
ago. With time, using the methods of multiple disciplines and heeding the inherited knowledge of tribal members, we may begin to understand the scale and scope of the imprint of traditional management upon the diet of the Klamath and Modoc people and upon the landscapes and the ecology of the larger Klamath Basin.

\begin{abstract}
Notes
${ }^{1}$ No fewer than 70 Klamath Tribes members have shared information on traditional plant management practices that inform the current paper. Quoted or paraphrased interviewees include: Robert Cole, Randolph Bobby David, Belvie Dillstrom, Neva Eggsman, Marilyn Hall, Dino Herrera, Alice Hobbs, Joseph Hobbs, Jerald Jackson, Barbara Kirk, Orin Kirk, Stephanie Ohles, Andrew Ortis, Karen Ray, Lynn Schonchin, Helen Crume Smith, Barbara Wright, and Mary Anne Wright. All research described in this manuscript was conducted with the direct oversight of the Klamath Tribes Culture and Heritage Department, including a tribally sanctioned informed consent process involving all interviewees identified here.
\end{abstract}

2 Spellings of Klamath and Modoc terms follows the standard of Barker (1963).

\title{
References Cited
}

Anderson, M. Kat.

2005 Tending the Wild: Native American Knowledge and the Management of California's Natural Resources. University of California Press, Berkeley.

Anderson, M. Kat and Thomas C. Blackburn, editors.

1993 Before the Wilderness: Environmental Management by Native Californians.

Ballena Press Anthropological Papers, No. 40. Ballena Press, Menlo Park.

Applegate, O.C.

1899 Report of agent for Klamath Agency to the Commissioner of Indian Affairs, September 26, 1899. In Report of the Commissioner of Indian Affairs, Part 1, pp. 309-15. U.S. Department of the Interior, Washington.

1902 Report of Agent for Klamath Agency to the Commissioner of Indian Affairs, 1902. In Report of the Commissioner of Indian Affairs, Part 1, pp. 30515. U.S. Department of the Interior, Washington.

Barker, Muhammad Abd-al-Raham.

1963 Klamath Dictionary. University of California Publications in Linguistics, No. 31. University of California Press, Berkeley.

Barrett, Samuel A.

1910 The material culture of the Klamath Lake and Modoc Indians of northeastern California and southern Oregon. In University of California Publications in American Archaeology and Ethnology. Volume 5, Number 4, pp. 239-92. University of California Press, Berkeley.

Boller, Henry A.

1972 Among the Indians: Four Years on the Upper Missouri, 1858-1862. ed. M.M. Quaife. University of Nebraska Press, Lincoln.

Boyd, Robert, ed.

1999 Indians, Fire and the Land in the Pacific Northwest. Oregon State University Press, Corvallis.

Brookfield, H.C.

1981 Intensification and disintensification in Pacific agriculture: a theoretical approach. In Human Population and Agroecosystems, eds. P. Pirie and A. Gomes, pp. 78-96. East-West Center, Honolulu.

Carlson, Roy L.

1957 Recent Artifacts. Klamath County Museum, Clearing House for News 1(3): 2-4.

Clarke, Samuel A.

1960 The Samuel A. Clarke Papers [1873], ed. B.K. Swartz. Klamath County Museum Research Papers, No. 2. Klamath County Museum, Klamath Falls. 
Clarke, William J.

1885 Rock piles and ancient dams in the Klamath Valley. American Antiquarian and Oriental Journal 7(1):40-41.

Cohen, Mark N. and G.J. Armelagos, editors. 1984 Paleopathology and the Origins of Agriculture. Academic Press, Orlando.

Couture, Marilyn Dunlap.

1978 Recent and contemporary foraging practices of the Harney Valley Paiute. Master's thesis, Department of Anthropology, Portland State University, Portland.

Coville, Frederick V.

1897 Notes on the plants used by the Klamath Indians of Oregon. In Contributions from the United States National Herbarium, Vol. 5, No. 2, pp. 87-108. U.S. Department of Agriculture, Division of Botany, Washington.

1904 Wokas, a primitive food of the Klamath Indians. In Annual Report for the U.S. National Museum for 1902, pp. 725-39. U.S. National Museum, Washington.

Cressman, Luther S.

1956 Klamath Prehistory: The prehistory of the culture of the Klamath Lake area, Oregon. Proceedings of the American Philosophical Society 46(4):375-513.

Curtin, Jeremiah.

n.d. Myths and Legends (Modoc). MS 1299, National Anthropological Archives, Smithsonian Institution, Washington.

Davidson, D.S.

1937 Snowshoes. Memoirs of the American Philosophical Society 6:1-207.

Denevan, William.

1992 The pristine myth: The landscape of the Americas in 1492. Annals of the Association of American Geographers 82(3):369-85.

Deur, Douglas.

2000 A Domesticated Landscape: Native American Plant Cultivation on the Northwest Coast of North America. Ph.D. thesis (Geography). Louisiana State University, Baton Rouge.

2002a A most sacred place: The significance of Crater Lake among the Indians of southern Oregon. Oregon Historical Quarterly 103(1):18-49.

2002b Huckleberry Mountain Traditional Use Study. U.S. Forest Service, Rogue River National Forest, Medford.
2004 Traditional Cultural Properties and Sensitive Resource Study, Klamath Tribes: Klamath River Project FERC Relicensing Documentation. The Klamath Tribes, Chiloquin.

2006 Traditional Cultural Properties Study: Wocus Bay, Grandma Rock, Olene Gap, and Saddle Mountain. U.S. Department of the Interior, National Park Service Historic Preservation Program, Washington.

2007 Culturally Modified Trees at Spring Creek: An Ethnographic Overview. Oregon Department of Transportation, Salem.

2008 In the Footprints of Gmukamps: A Traditional Use Study of Crater Lake National Park and Lava Beds National Monument. U.S. Government Printing Office, Washington.

Deur, Douglas and Nancy Turner, editors. 2005 Keeping it Living: Traditions of Plant Use and Cultivation on the Northwest Coast of North America. University of Washington Press, Seattle.

French, David.

1999 Aboriginal control of huckleberry yield in the Northwest. In Indians, Fire, and the Land in the Pacific Northwest, ed. Robert Boyd, pp. 31-35. Oregon State University Press, Corvallis.

Gatschet, Albert S.

1890 The Klamath Indians of Southwestern Oregon. Contributions to North American Ethnology, Volume 2, Numbers 1-2. U.S. Geographical and Geological Survey of the Rocky Mountain Region, Washington.

Gleason, Susan.

1997 The Great Western Root: Construction and Consideration of Behavioral Chains Relative to Resource Management. M.A. thesis (Anthropology). University of California, Riverside.

Hrdlička, Aleš.

1905 Head deformation among the Klamath. American Anthropologist 7: 360-61.

Hunn, Eugene S.

2000 On the Relative Contribution of Men and Women to Subsistence among Hunter-Gatherers of the Columbia Plateau: A Comparison with Ethnographic Atlas Summaries. In Ethnobotany: A Reader, ed. P.E. Minnis, pp. 184-213. 
University of Oklahoma Press, Norman.

Hunn, Eugene and David French.

1981 Lomatium: A key resource for Columbia Plateau native subsistence. Northwest Science 55:87-94.

Hunn, Eugene S. and J. Selam.

1990 Nch'iWána, "The Big River": Middle-Columbia Indians and Their Land. University of Washington Press, Seattle.

Hunn, Eugene S., Nancy J. Turner, and David H. French.

1998 Ethnobiology and Subsistence. In Handbook of North American Indians, Volume 12: Plateau, ed. Deward E. Walker, Jr., pp. 525-545. Smithsonian Institution Press, Washington.

Kerns, Becky K., Susan J. Alexander, and John D. Bailey.

2004 Huckleberry abundance, stand conditions, and use in Western Oregon: Evaluating the role of forest management. Economic Botany 58(4):668-678.

Knack, Martha C. and Omer C. Stewart. 1984 As Long as the River Shall Run: An ethnohistory of Pyramid Lake Indian Reservation. University of California Press, Berkeley.

Kroeber, Alfred L.

1925 Handbook of the Indians of California. Bureau of American Ethnology, Bulletin 78. Washington.

Kuhnlein, Harriet V. and O. Receveur. 1996 Dietary change and traditional food systems of indigenous peoples. Annual Review of Nutrition 16:417-42.

LaLande, Jeff and Reg Pullen.

1989 Burning for a "fine and beautiful open country": Native uses of fire in southwestern Oregon. In Indians, Fire and the Land in the Pacific Northwest: An Anthology of Papers on Indian Use of Fire in the Environment, ed. R.T. Boyd, pp. 185-218. Oregon State University Press, Corvallis.

Lepofsky, Dana, Douglas Hallett, Ken Lertzman, Rolf Mathewes, Albert McHalsie, and Kevin Washbrook.

2005 Documenting Precontact Plant Management on the Northwest Coast: An example of prescribed burning in the central and upper Fraser Valley. In Keeping it Living: Traditions of plant use and cultivation on the northwest coast of North America, eds. D.E. Deur and N.J.
Turner, pp. 218-39. University of Washington Press, Seattle.

Lewis, Henry T.

1982 A Time for Burning. Occasional Publication No. 17. University of Alberta, Boreal Institute for Northern Studies, Edmonton.

MacNeish, Richard S.

1992 The Origins of Agriculture and Settled Life. University of Oklahoma Press, Norman.

Mack, Cheryl A. and R.H. McClure.

2002 Vaccinium processing in the Washington Cascades. Journal of Ethnobiology 22(1):35-60.

Minto, John.

1898 A paper on forestry interests. In Report of the Secretary of the State Land Board of Horticulture on Forestry and Arid Lands, Oregon, ed. W.H. Leeds. Oregon State Printer, Salem.

Peacock, Sandra L.

1998 Putting Down Roots: The emergence of wild plant food production on the Canadian Plateau. Ph.D. dissertation, School of Environmental Studies, University of Victoria, Victoria.

Peacock, Sandra L. and Nancy J. Turner. 2000 "Just like a garden": Traditional plant resource management and biodiversity conservation on the British Columbia Plateau. In Biodiversity and Native America, eds. P. Minnis and W. Elisens, pp. 133-179. University of Oklahoma Press, Norman.

Piperno, Dolores R. and Deborah M. Pearsall.

1998 The Origins of Agriculture in the Lowland Neotropics. Academic Press, San Diego.

Pullen, Reginald J.

1996 Overview of the Environment of Native Inhabitants of Southwestern Oregon, Late Prehistoric Era. U.S. Department of Agriculture, Rogue River National Forest, Medford.

Ray, Verne F.

1963 Primitive Pragmatists: The Modoc Indians of Northern California. University of Washington Press, Seattle.

Rindos, David.

1984 The Origins of Agriculture: An Evolutionary Perspective. Academic Press, Orlando.

Spencer, Robert F.

1952 Native myth and modern religion 
among the Klamath Indians. Journal of American Folklore 65(257):217-26.

Spier, Leslie.

1930 Klamath Ethnography. University of California Publications in American Archaeology and Ethnology, Vol. 30. University of California Press, Berkeley.

Stern, Theodore.

1956 The Klamath Indians and the treaty of 1864. Oregon Historical Quarterly 57(3):229-73.

1965 The Klamath Tribe: A People and their Reservation. American Ethnological Society, Monograph No. 41. University of Washington Press, Seattle.

1998 Klamath and Modoc. In Handbook of North American Indians, Vol. 12: Plateau, ed. Deward E. Walker Jr., pp. 446-66. Smithsonian Institution, Washington.

Swetnam, Thomas W.

1984 Peeled ponderosa pine trees: A record of inner bark utilization by Native Americans. Journal of Ethnobiology 4(2):177-190.

Swezey, Sean L., Steven R. James, and Suzanne Graziani.

1975 Socio-Religious Aspects of Resource Management, and Practices of Warfare among California Indians. Contributions of the University of California Archaeological Facility, Vol. 23. University of California Press, Berkeley.

Thoms, Alston V.

1989 The Northern Roots of HunterGatherer Intensification: Camas and the Pacific Northwest. Ph.D. thesis (Anthropology). Washington State University, Pullman.

Trusler, Scott and Leslie Main Johnson.

2008 "Berry Patch" As a Kind of Place: The Ethnoecology of Black Huckleberry in Northwestern Canada. Human Ecology 36(4):553-68.

Williams, Nancy M. and Eugene S. Hunn. 1982 Resource Managers: North American and Australian Hunter-Gatherers. Westview, Boulder.

Wilson, Horace.

1906 Report of Agent for Klamath Agency to the Commissioner of Indian Affairs, 1906. In Report of the Commissioner of Indian Affairs. Part 1, pp. 33041. U.S. Department of the Interior, Washington.

Winterhalder, Bruce and Douglas Kennett.

2006 Behavioral ecology and the transition from hunting and gathering to agriculture. In Behavioral Ecology and the Transition to Agriculture, eds. D. Kennett and B. Winterhalder, pp. 1-21. University of California Press, Berkeley.

Zakoji, Hiroto.

1953 Klamath Culture Change. M.A. thesis (Anthropology). University of Oregon, Eugene.

Zeder, Melinda A., Daniel G. Bradley, Eve Emshwiller and Bruce Smith, editors.

2006 Documenting Domestication: New Genetic and Archaeological Paradigms. University of California, Berkeley. 